also visited, and one or two engineers in the company examined, with interest, the last-named structure. In this agreeable manner the time was spent until the party departed by the return train to London.

\title{
REFERENCE.
}

Geological Survey Map, Sheet 52, SE. and S.W.

\section{On the Lower Divisions of the Carboniferous Rocks of the Forest of Dean.}

By E. Wethered, F.G.S., F.C.S., F.R.M.S.

(Read July 6, 1888.)

In Gloucestershire we have two coal-fields, that of Bristol and that of the Forest of Dean. These two, together with that of Somersetshire, are regarded as outliers of the great South Wales coal-field. Sir Andrew Ramsay states * that the separation was brought about by long-continued denudation, which has swept away thousands of feet of strata bent into anticlinal and synclinal curves. He further remarks $\dagger$ that "the intervening spaces are anticlinal and the basins synclinal curres, and therefore it is not only possible, but probable, that other coal-basins may lie far to the east beneath the Oolitic, Cretaceous, and Eocene strata of the London basin." These conclusions have generally been accepted, and I am not going to dispnte their correctness. I shall, however, show that in the Forest of Dean there are geological feutures which differ greatly from those of contemporaneous rocks in the Bristol area. As this is important, and to a great extent new, $I$ shall in this paper have something to say as to the correlation of the Carboniferous rocks of the Forest of Dean with those of Bristol. But as this paper is to have special reference to the visit of the Association to the Forest of Dean, I shall confine myself to strata below the Coal Measures, as it will be impossible on that occasion to see more.

As typical of the Lower Carboniferous rocks of the Bristol area, I take the exposure in the gorge of the River Aron at Clifton, which, as Sir Henry De la Beche pointed out, $\$$ does not

* 'Physical Geology and Geography,' fifth edition, p. 35 (1878).

+ Loc. cit., p. 122.

‡ 'Mem. Geol. Survey,' Vol. i, p. 112. 
E. WETHERED ON THE LOWER CARBONIFEROUS ROCKS. 511

materially differ in thickness from the same formation in the Mendip Hills of Somersetshire and in South Pembrokeshire. Sir Henry gave * the thickness as follows :-

Feet.

Upper mixture of Sandstone, Marls, and Limestones $\quad \ldots \quad 400$

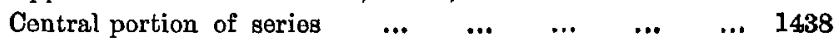

$\begin{array}{lllllllll}\text { Lower shales } & \ldots & \ldots & \ldots & \ldots & \ldots & \ldots & \ldots & 500\end{array}$

$\overrightarrow{2338}$

In a recent paper of mine $\mathrm{I}$ have made some alteration in the above classification, thus :-

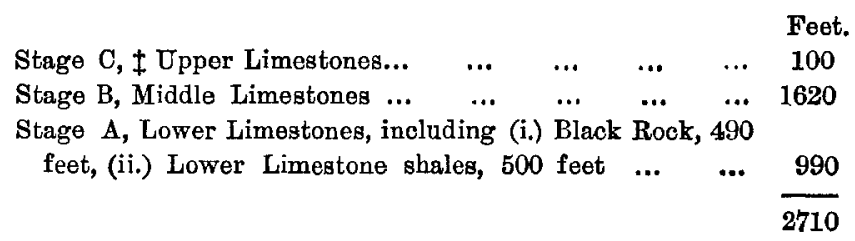

The Carboniferous Limestone series in the Forest of Dean have not received anything like the amount of attention which has been bestowed upon the same rocks in the Bristol coal-field. Sir Henry De la Beche gives a section $\S$ which he compares with that of the Aron, and points out that there is a great diminution in the thickness of the beds in the Forest of Dean, which he estimates as follows :-

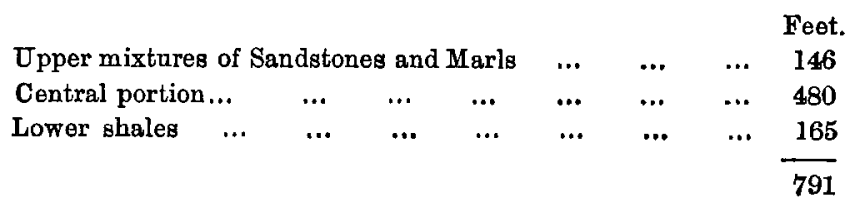

Thus, Sir Henry remarks, " the central portion of the Carboniferous series, 1,438 feet in depth at Bristol, become 480 feet in the Forest of Dean. The lower beds are diminished about onethird, the central portion the same, and the upper beds very nearly in the same proportion."

* Loo. cit., p. 129.

+ 'Quart. Journ. Geol. Soc.,' Vol. xliv, p. 187 (1888).

$\ddagger$ The introduction of the term stage and the letters refer to Professor Hull's classification, 'Quart. Journ. Geol. Soc.' Vol. xxxiii, p. 631 (1877).

$\S$ 'Mem. Geol. Survey,' Vol, i, p. 129.

|l Loc. cit., p. 129. 
In a paper which I communicated to the 'Geolngical Magazine' * I classified the rocks thus :-

$$
\begin{array}{cccccccc}
\multicolumn{1}{c}{\text { Stage C, Upper Limestones, including the Whitehead and }} & \\
\text { Crease Limestones } & \ldots & \ldots & \ldots & \ldots & \ldots & \ldots & 116 \\
\text { Stage B, Middle Limestones } & \ldots & \ldots & \ldots & \ldots & \ldots & 360 \\
\text { Stage A, Lower Limestones } & \ldots & \ldots & \ldots & \ldots & \ldots & 130 \\
& & & & & & \frac{606}{}
\end{array}
$$

Since that paper was written I have examined exposures of the upper Limestones not previously available, especially one at the Wilderness Cement Works near Mitcheldean, which has enabled me to make a more detailed examination. These details will be referred to later on, and I will only mention here that the thickness of 116 feet may be a fair average for the whole coal-field, but it is tno great for the northern end, where the upper series are not so well developed as at the southern end. The following statement will be more correct for the former district, though the beds vary considerably even over a small area :-

$$
\begin{array}{lllllllll}
\multicolumn{9}{c}{\text { Upper Limestones. }} \\
\text { Whitehead Limestone } & \ldots & \ldots & \ldots & \ldots & \ldots & \ldots & 30 \\
\text { Crease Limestone... } & \ldots & \ldots & \ldots & \ldots & \ldots & \ldots & \mathbf{3 5} \\
& & & & & & & 65
\end{array}
$$

Above the Whitehead series sandy beds appear in some places associated with argillaceous flagstones and some small plant remains. These constitute a thickness of about 15 or 20 feet and are succeeded by the true Millstone grit. Sir H. De la Beche puts the thickness of the Millstone grit in the Bristol area at 950 feet, and that of the Forest of Dean at 270 feet, which I accept.

\section{The Lower Limestone Shales.}

An examination of the Geological Survey Map shows that the Old Red Conglomerate appears as a belt around the edges of the Carboniferous Limestone. This conglomerate is followed by a remarkable series of many-coloured sandy beds and green micaceons shales, which lie between it and the Carboniferous Lower Limestone shales. These are the so-called "Passage beds." In the 'Proceedings of the Cotteswold Naturalists' Field Club' for 1867 there is a detailed section of them, as they were exposed in the "deep cutting" near Drybrook, made by Mr. W. C. Lucy and Mr. John Jones. Since then the beds have been cut

$$
\text { * n.s., Dec. iii, Vol. iii (1886), p. } 529 .
$$


through in the course of the new railway from Coleford to Monmouth, and for a very carefully-made section (fig. 1) I am indebted to Mr. A. Stannard, C.E., the engineer who made the railway.

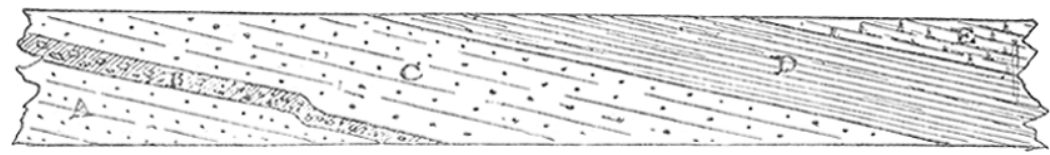

Fia. 1. Section at Redbrook, Gloucestershire, exposed in cutting on the Coleford Railway, showing beds between the Old Red Conglomerate and the Lower Limestone Shales.

A. Old Red Sandstone. B. Old Red Conglomerate. C. Sandstone. D. Sandy Calciferous Beds and Shales. H. Lower Limestone Shales.

Horizontal scale four times the vertical scale.

The old Red Conglomerate is here shown as only 12 feet thick, and is followed by red sandy beds, which may, perhaps, be termed Upper Old Red Sandstone. Mr. Stannard put these at 82 feet. Then follows 70 feet of loose Calcareous Sandstone, in some beds of which are nodular fragments of Limestone. Messrs. Jones and Lucy give the total thickness of the beds exposed in the deep cutting near Drybrook at 247 feet. A reference to the Geological Map will show that the two exposures of the beds referred to are sufficiently far apart to dispose of the idea that they are characteristic of any one locality, and to justify the belief that they underlie the limestone shales throughout the area of the coal-field. Among the minerals which $I$ have detected in these beds are, mica, very abundant in green shales, felspar, tourmaline, zircon, rutile(?), and quartz. The remarkable variation in colour which the strata present is due to oxides of iron and manganese.

The Lower Limestones consist of one division only, which corresponds with the Lower Limestone shales of the West of England. The "Black Rock," or upper portion of the Lower Limestones of the British coal-field, is not represented in the Forest of Dean. The Black Rock is a limestone made up chiefly of the remains of Encrinites, and constitutes the local Encrinite Limestone at Bristol. In the Lower Limestone shales of the Forest of Dean there is one very interesting Encrinite bed, which is typical of the northern end of the coal-field, but it is only one foot thick, and cannot be correlated with the Black Rock. Some 
of the Encrinite joints in the Forest of Dean bed are interesting from the fact that the central portion is pentagonal, which centre is surrounded by a circular outer margin. Specimens of these are figured in my paper in the 'Geological Magazine,'* but the photographic process by which the objects were reproduced was not suitable, and the figures are consequently unsatisfactory.

The other limestones which constitute the Lower Limestones of the Forest of Dean are some of them largely made up of Ostracoda; some beds are little else than the valves of those small Crustacea. Polyzoa are numerous in the Encrinite bed, and occur in others. Rhynchonella pleurodon is very numerons in some of the black shales between the beds of limestone, and on the shales weathering may be collected in great numbers. In these shales I have detected the spores of plants, details as to which will be found in the 'Proceedings of the Cotteswold Naturalists' Field Club' for 1883-4. They are interesting as being allied to spores which Mr. E. T. Newton $†$ discovered in Tasmanite and "Australian White Coal," and also to similar vegetable remains which occur in great abundance in the Huron shales of Ohio. The exact horizon of these American shales is a debateable question, but they belong either to the Upper Devonian or Lower Carboniferous. Consequently the Black shales of Ohio occupy much the same position as those in the Forest of Dean, and it is, therefore, interesting to discover these vegetable remains which are closely allied, in strata of about the same geological horizon, though in localities so far apart. Sir William Dawson regards $\ddagger$ the spores as Rhizocarps, and as belonging to his genus Sporangites.

There is also an organism of some interest which was first discovered in the Lower Limestone shales of the Forest of Dean, and the Association will have an opportunity of obtaining limestone largely made up of it. I refer to my genus Mitcheldeania. It was first described in the 'Geological Magazine,' $\$$ but for the same reason that the other illustrations in the plate are not satisfactory, so with the figure of Mitcheldeania it is difficult to form a correct opinion as to the true nature of the organism. I have since described it in the 'Proceedings of the Cotteswold Naturalists'

* n.s., Dec. iii, Vol, iii (1886), Pl. xiv, Figs. 1 and 2.

† ' Geol. Mag.', n.s., Dec. it, Vol. ii (1875), p. 337.

¥ 'Geological History of Plants,' p. 52, 1888.

\$ n.s., Dec. Jii, Vol. iif (1886), Pl. xir, Fig. 6, p. 535. The name is taken from the locality, Mitcheldean. 
Field Club,"* and Professor Alleyne Nicholson has referred to it in the 'Geological Magazine.' $\dagger$ Briefly stated, the genus Mitcheldeania is an organism consisting of systems of tubuli, the whole occurring in oval masses, or encrusting the remains of other organisms. The larger tubuli appear to be zoöids, and the smaller probably contained the living matter. There is also interstitial tissue, which is traversed by still more minute branching tubuli. The first species of the genus I named $M$. Nicholsoni, after Professor Nicholson, and provisionally referred it to the Hydractiniida, as allied to the Stromatoporoids. Professor Nicholson has since described $\ddagger$ and figured a larger species, $\boldsymbol{M}$. gregaria, from the South of Scotland, and in the course of his remarks says: "In spite of the extreme minuteness of its tissues, the genus Mitcheldeania may, I think, be referred with tolerable certainty to the Colenterata. Admitting its Coelenterate affinities, it would seem almost certain that the genus must be placed in the series of the Hydrozoa. There is, however, no known group of this class within which Mitcheldeania can be satisfactorily located. Its closest affinities seem to be with the Hydrocorallines, and in this connection I would particulariy draw attention to the resemblance of the interstitial tissue of Mitcheldeania to the conenchymal tissue of certain species of Allopora. On the other hand, all the known Hydrocorallines possess zoöidal tubes which are enormously larger than those of Mitcheldeania; and there are other morphological features in the latter genus which would preclude its being actually placed, with our present knowledge, in the group of the Hydrocorallina.

The following is a list of the fossils which have been found in the Lower Limestone shales of the Forest of Dean :-

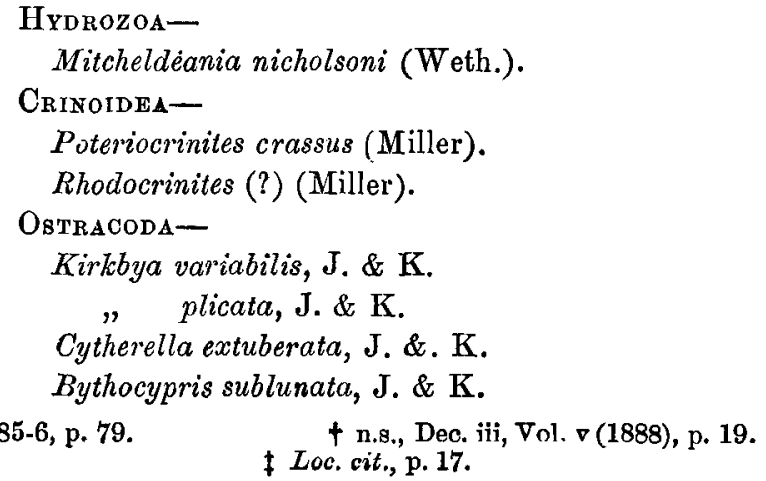


Darwinula berniciana (?), Jones.

Leperditia okeni, Munster.

Polyzoa -

Fenestella tuberculo-carinata (Ether., junr.).

Ceriopora similis (Phill.).

Rhabdomeson gracile (Phill.).

BRACHIOPODA-

Athyris royssii (L'Eveillé).

Rhynchonella pleurodon (Phill.). Gasteropoda-

A fossil allied to Murchisonia angulata.

The only reference which $I$ need make to the above list relates to the Ostracoda. My specimens were sent to Professor Rupert Jones and Mr. J.W. Kirkby, who in a note appended to a paper of theirs* refer to the discovery of the following Ostracoda from a boring at Gayton, in Northamptonshire:-Kirkbya variabilis, $K$. plicata, Cytherella extuberata, C. attenuata, Bythocypris sublunata, and Macrocypris Jonesiana. The authors then refer to the list which I give of forms found in the Forest of Dean, and make the following remarks:- "Quite recently Mr. E. Wethered, F.G.S., of Cheltenham, has favoured us with specimens from the Lower Limestone shale of the Forest of Dean. Curiously enough, these specimens are almost exactly similar in species and individual abundance to those of the Gayton Boring."

The Middle Limestone.

I have not myself as yet been fortunate enough to obtain a fossil from these beds, and the explanation appears to be that they are extensively dolomitized. I cannot speak so confidently of the limestone at the southern outcrop, but all the exposures that I have seen are those of dolomitized limestone. An analysis made by Mr. Ernest Wiltshire, F.G.S., and myself gave the following results :-

$\begin{array}{lllllr}\text { Moisture } & \ldots & \ldots & \ldots & \ldots & 02 \\ \text { Organic matter } & \ldots & \ldots & \ldots & 6 \cdot 17 \\ \text { Carbonic acid ... } & \ldots & \ldots & \ldots & 44 \cdot 01 \\ \text { Insoluble residue } & \ldots & \ldots & \ldots & 1 \cdot 06 \\ \text { Soluble silica } & \ldots & \ldots & \ldots & \ldots & \cdot 10 \\ \text { Ferrous oxide } \ldots & \ldots & \ldots & \ldots & .63 \\ \text { Lime ... } & \ldots & \ldots & \ldots & \ldots & 30 \cdot 24 \\ \text { Magnesia } & \ldots & \ldots & \ldots & \ldots & 17 \cdot 50 \\ \text { Soda ... } & \ldots & \ldots & \ldots & \ldots & .25 \\ & & & & & \frac{99 \cdot 98}{}\end{array}$

* 'Quart. Journ. Geol. Soc.,' Vol. xlii, p. 504 (1886). 
Iron ore occurs in the Middle Limestone, and this is especially so at the northern end of the Coal-field, where it was worked by the Romans, as well as in recent times. Referring to the occurrence of this hæmatite, Sir H. De la Beche says:- "The Dean Forest section presents us with an interesting local accumulation of peroxide of iron intermingled with the calcareous deposits of the time; so that we should regard the iron as having constituted as much a portion of the rocks in a particular part of the general series as any other marked beds. . . . Although, in endeavouring to account for the position of the iron ore in the Carboniferous Linestone of Dean Forest, we may, from existing knowledge, be led to suppose that it was formed in the sea, anid the marine accumulations with which it is associated, so that it may not have been a bog iron ore of that geological period, still its dispersion at the same time over so wide an area would induce us to infer that the peroxide was thrown down from water in which the iron had previously been, in some soluble form, spread over the space required."* The result of my examination of these ores makes it difficult to accept the explanation advanced by Sir H. De la Beche. It is true that in some cases the ore has a stratified appearance, but $I$ am still disposed to regard the deposit as an after in-filling, or rather, precipitation. In the ' Cxeological Magazine' for 1882 (pp. 522-525) there is a paper of mine ' On the Origin of the Hematite Deposits in the Carboniferous Limestone,' fron which I venture to quote :"To sum up my conclusions on the subject of this paper, I regard the so-called pockets of hematite in the interior of the Limestone as caverns, into which water has percolated charged with the carbonates of lime and iron. On the excess of carbonic acid being given off, and a complete saturation taking place, carbonate of lime first separated in the crystalline state ; and subsequently, when oxidation was possible, peroxide of iron was thrown down. As to the source from which the iron was derived, I think it possible that some portion may have come from the Coal Measures and Millstone grit prior to denudation by the Triassic Sea, but that the greater portion was derived from the Trias rocks by the percolation of water containing carbonic acid." In support of the conclusions just stated, I make another short quotation from the same paper (p. 523) :- "A practical instance of what I have * 'Mem. Geol. Survey,' Vol. i, p. 130. 
just described (referring to the deposition of iron oxide) was seen when down the Easton Colliery, near Bristol, a few months since. Water was issuing from old workings, and on flowing into a road of the mine where fresh air was travelling, a ferruginous deposit took place. Again, I once had occasion to descend an old shaft of a coal-mine which had not been worked for many years; near the bottom of the shaft water was issuing from the old workings, and there was a deposit of peroxide of iron about half-aninch deep. On penetrating further into the workings where the atmosphere had been, until recently, strongly diluted with carbonic acid, there was an entire absence of such a deposit." Should the Association visit the Carth iron-mine, near Cardiff, I think the Members will come to the conclusion that the so-called pockets are really caverns, or underground water-courses, in which iron has been deposited in the way $I$ bave indicated.

Comparing the niddle division of the Carboniferous Limestone series of the Forest of Dean with the contemporaneous rocks in the Bristol and Somersetshire coal-fields, we again find a marked difference. In the latter areas, the Limestone is largely made up of foraminifera and Calcisphorce, and to a less extent of fragments of shells, polyzoa, joints of crinoids, and corals. Dolomite occurs at three horizons, but is unimportant.

\section{Upper Limestones.}

I have before stated that the Upper Series consists of two distinct Limestones, namely, the Crease and the Whitehead. At what may be regarded the top of the Middle Limestone I have observed an Encrinital bed, and it is at this horizon that I draw the line between the Middle and Upper Series. This Encrinital Limestone varies considerably in thickness : in some places it is less than one foot; whilst in others it is as much as four feet or more. This variation in thickness is a feature of the Upper Limestones ; and indeed, it would be difficult to find two localities where identical measurements could be obtained.

\section{The Crease Limestone.}

It is in this Limestone that the chief deposit of hæmatite ores occurs. The origin of this mineral in the Middle Limestone has been dealt with, and what $I$ have said in reference to it applies also to that which occurs in the "Crease." 
The structure of the rock in close proximity to the ore is peculiar, and difficult to understand. Seen in thin sections it appears to be made up of angular calcareous fragments, and in my paper in the 'Geological Magazine' * I have called it a calcareous grit. I an not, however, sure that $I$ was right in so terming it, for more extensive observations lead me to believe that it is a limestone which has become crystalline.

Other portions of the "Crease," recently exposed at the Wilderness Cement Works near Mitcheldean, are very fossiliferous, the fossils being chiefly Producti, but much crushed. Thin sections show remains of these shells, especially the spires, some joints of Encrinites, a few Calcisphcera and granular calcareous fragments which could not be determined. The upper beds of the Crease exhibit a fine Oolitic structure. The nucleus of the granules is sometimes a portion of an Encrinite joint, but as a rule the nuclei are not well preserved.

\section{The Whitehead Limestone.}

The beds which constitute the uppermost of the whole Carboniferous Limestone series in the Forest of Dean are locally known as the "Whitehead" Limestone. The name appears to have been suggested from the peculiar whiteness of some of the beds, and from the fact that no hamatite occurs in them, and consequently, in local mining dialect, it is termed the "head."

The true limestones are separated by shales and argillaceous limestones, and about the middle of the series there is a peculiar deposit of concretionary or nodular limestone and blue calcareous clay, the whole averaging about 7 feet thick. The series terminates in a thickness of about 12 feet of white limestone, tinged with gray, locally known as the "Whitehead Block."

The following are my notes on thin sections made from specimens of the above Limestones.

1.-The bed which rests upon the "Crease," and is locally termed the "Lid." It is made up of small variously-shaped fragments of granular Limestone. The only organisms which could be determined were Calcispharce, and of these there were a considerable number, well preserved. The spaces between the granular fragments and organisms were filled in with clean crystalline calcite.

* 'Geol. Mag.,' n. s., Vol. iii, Dec. iii, p. 337 (1886). 
Section No. 2.-A greyish White Limestone, composed of a spiral shell, foraminifera, polyzoa, and obscure calcareous fragments.

Section No. 3.-From the concretionary bed. The nodules show the same whiteness which is typical of most of the Whitehead Limestone. They occur as large as an inch in diameter, and contain a variety of organic remains, but all badly preserved.

Section No. 4.-From the Whitehead Block. Chiefly made up of dark granular calcareous fragments, with foraminifera and some Calcisphara.

Comparing the Upper Limestones of the Forest of Dean with the same division in the Bristol area, we find a very considerable difference. In the former district, as I have shown, the upper series are characteristic and well defined, but in the Bristol Coalfield the Middle Limestone simply becomes mixed with grits and argillaceous beds. The "Crease" and "Whitehead" Limestones (as distinct divisions) are not represented.

\section{The Millstone Grit.}

Following the "Whitehead Block," we come to from 15 to 20 feet of loose sandy beds and argillaceous flagstones. In some of these I have met with small plant-remains, and, in one instance, with an undonbted shell. These beds pass into yellow sandstone, made up of well-rounded quartz grains, and containing Lepidodendra. This is the base of the true Millstone Grit, which may be said to consist of a loose sandstone of yellow, red and mottled colours, resembling a Triassic sandstone rather than what is understood as Millstone Grit in the South Wales, Bristol and Somersetshire Coal-fields. One of the beds which I have observed near Mitcheldean, and at Sudely, near Coleford, is interesting on account of its great similarity to the Old Red Conglomerate. The typical Old Red Conglomerate of Herefordshire and Gloucestershire contains pebbles, which Sir Henry De la Beche calls "veinstone quartz." * In the bed of Millstone Grit referred to, these same pebbles occur, associated, as in the Old Red Conglomerate, with small quartz grains, the whole being loosely cemented together by a ferruginous siliceous matrix. From this evidence I conclude that the same land must have been undergoing denudation during the tine that the particular bed of 
Millstone Grit was deposited, as during the deposition of the Old Red Conglomerate.

In the Bristol, Somersetshire, and South Wales Coal-fields the Millstone Grit is a hard, slightly pink quartzite, and therefore differs lithologically from that in the Forest of Dean, but not in actual chemical composition, as the following analyses prove :-

\begin{tabular}{|c|c|c|c|c|c|c|}
\hline & & & & $\begin{array}{c}\text { Bristol } \\
\text { (Brandon } \\
\text { Hill). }\end{array}$ & $\begin{array}{c}\text { South } \\
\text { Wales } \\
\text { (Pentyrch). }\end{array}$ & $\begin{array}{c}\text { Forest of } \\
\text { Dean } \\
\text { (Drybrook). }\end{array}$ \\
\hline Silica & ... & ... & $\ldots$ & $97 \cdot 80$ & $96 \cdot 63$ & $98 \cdot 06$ \\
\hline Alumina ... & ... & $\ldots$ & $\ldots$ & $\cdot 47$ & $1 \cdot 15$ & $\cdot 30$ \\
\hline Oxide of iron & ... & ... & .. & $\cdot 80$ & $\cdot 70$ & $\cdot 50$ \\
\hline Lime $\quad \ldots$ & $\cdots$ & ... & $\ldots$ & $\cdot 44$ & $\cdot 55$ & 33 \\
\hline Organic matter & $\cdots$ & $\cdots$ & $\ldots$ & $\cdot 17$ & $\cdot 30$ & $\cdot 20$ \\
\hline Carbonic acid & $\cdots$ & $\cdots$ & ... & 39 & $\cdot 20$ & $\cdot 30$ \\
\hline Moisture... & $\ldots$ & ... & $\ldots$ & $\cdot 22$ & $\cdot 10$ & - \\
\hline \multirow[t]{2}{*}{ Alkalies ... } & $\ldots$ & $\ldots$ & ... & - & trace. & trace. \\
\hline & & & & $100 \cdot 29$ & $99 \cdot 63$ & $99 \cdot 69$ \\
\hline
\end{tabular}

The Millstone Grit, as in other coal-fields, passes up into the Coal Measures. The lowest seam of coal is that of the Lower Trenchard, 1 foot 2 inches thick. There are in all 20 principal seams, varying from eight inches to between, as in the case of the "Coleford High Delf," four and five feet. 